\title{
Bone destruction caused by orbital pseudotumor
}

\author{
Kemik yıkımına neden olan orbital psödotümör
}

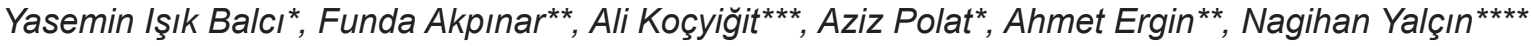 \\ *Pamukkale Üniversitesi Tıp Fakültesi, Çocuk Hematoloji ve Onkoloji Bölümü \\ **Pamukkale Üniversitesi Tıp Fakültesi, Çocuk Hastalıkları ve Sağlığı AD, Denizli \\ ${ }^{* * *}$ Pamukkale Üniversitesi Tıp Fakültesi, Radyoloji AD, Denizli \\ ****Pamukkale Üniversitesi Tıp Fakültesi, Patoloji AD, Denizli
}

\begin{abstract}
A four-year-old boy was administered with periorbital swelling and ptosis of his right eye. His computerized tomography scans showed bone destruction of right orbital lateral wall. In his histopathological examination there was eosinophil dominant cell infiltration, which was compatible with chronic inflammation. He was treated with oral prednisolone. After treatment, complete resolution of bone destruction and clinical improvement were observed. To the best of our knowledge, this was the first pediatric case with orbital pseudotumor causing bone destruction.
\end{abstract}

Pam Med J 2015;8(2):128-131

Key words: Orbital pseudotumor, bone destruction.

\section{Özet}

Dört yaşında erkek hasta, sağ göz etrafında şişlik ve göz kapağında düşüklük şikayeti ile başvurdu. Hastanın bilgisayarlı tomografi görüntülemesinde sağ orbital lateral duvarda kemik yıkımı olduğu görüldü. Histopatolojik incelemesinde kronik inflamasyon ile uyumlu eosinofilden yoğun infilamasyon saptandı. Oral prednizolon tedavisi verilen hastanın klinik bulgularının ve kontrol tomografisinde kemik yıkımının düzeldiği gözlendi. Hastamız araştırmalarımıza göre kemik yıkımına neden olan ilk pediatrik orbital psödotümör vakası olmasıdır.

Pam Tıp Derg 2015;8(2): 128-131

Anahtar sözcükler: Orbital osödotümör, kemik yıkımı.

\section{Introduction}

Pseudotumors are benign, idiopathic, non-specific lesions, which can affect nearly all parts of body, but the main parts usually involved are the lungs and orbit. It is the third common orbital lesion of adults however it is very rare in childhood [1]. Etiology is unknown. Autoimmunity, infections or trauma could be accused for pseudotumors [2]. Unilateral propitosis is the most common symptom for the adult population while for children, as ocular symptoms like palpable mass and ocular motility restriction are the most common ones. On the other hand, constitutional symptoms (headache, emesis, anorexia, abdominal distress, weight loss etc.) can also be seen [2]. It is benign condition, usually with no intracranial defect. In the literature about orbital pseudotumors, only four adult orbital pseudotumor cases with bone destruction were reported [3, 4]. Our case was the first pediatric patient diagnosed with orbital pseudotumor causing bone destruction.

\section{Case report}

Previously healthy four-year old boy admitted to our clinic with symptoms of swelling and ptosis in the right eye (Figure 1). He has been suffering from the right eye swelling for two months and he took a ten days-long intravenous sulbactam ampicilin treatment $(150 \mathrm{mg} / \mathrm{kg} /$ day). He then referred to our clinic with differential diagnosis of malignancy and orbital cellulites.

Yasemin Işık Balcı

Yazışma Adresi: Pamukkale Üniversitesi Tıp Fakültesi, Çocuk Hematoloji ve Onkoloji Bölümü e-mail: dryibalci@gmail.com 


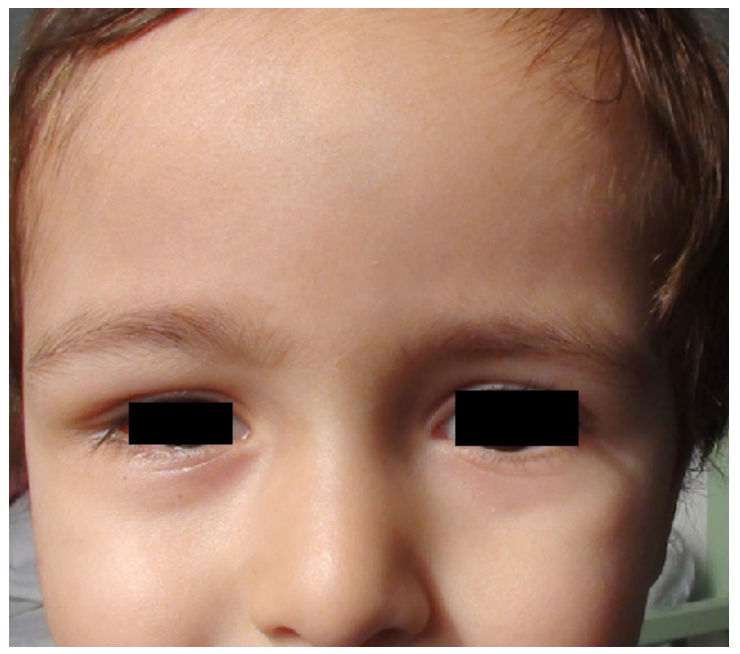

Figure 1. A four-year-old boy with periorbital swelling: before treatment.

His physical examination was normal, except his right periorbital swelling, ptosis and hypersensitivity. His visual acuity was 20/20 bilaterally and there was not any visual defect. His neurological examination was also normal. His laboratory investigation was as follows: C-reactive protein, $0.4 \mathrm{mg} / \mathrm{dL}(0-0.5 \mathrm{mg} / \mathrm{dl})$; white blood cells, $13910 \mu / \mathrm{L}$ (peripheral smear: $12 \%$ eosinophils, $66 \%$ polimorphonuclear leukocytes and $12 \%$ lymphocytes, no atypical cells or blasts. erythrocyte morphology was normochromic and normocytic); platelets, $471000 \mu / \mathrm{L}$; hemoglobin, $11.5 \mathrm{~g} / \mathrm{dL}$; hematocrit, $\% 36$; lactate dehydrogenase, uric acid, erythrocyte sedimentation rate, thyroid function tests were normal. His renal function, liver function tests and electrolytes were normal. There was not history of trauma or infection. His ANA, anti DNA was also normal. His tests were negative for parasitic infections. His orbital computed tomography (CT) showed a hypodens rounded shaped soft tissue lesion at the lateral wall of the right orbit with bone destruction (Figure 2). His orbital magnetic resonance imaging (MRI) was same as CT scan, showing that a soft tissue mass lesion causing zygomatic bone destruction. Due to place of lesion, excisional biopsy could not be performed, so for differential diagnosis, fine needle biopsy was done and histopathological examination and histopathological examination showed chronic inflammation with eosinophil dominant inflammatory cell infiltration. Immunohistochemically, macrophages including the giant cells were positive for CD68 and negative for S100 and CD1a. For orbital cellulites he was treated with intravenous ceftriaxone (75 mg/kg/day) and teicoplanin (10 mg/kg/day) for ten days, but no regression was observed. In relation with the histopathologic result and non-responsiveness to antibiyotherapy, it was thought as orbital pseudotumor and the child was treated with oral prednisolone $(2 \mathrm{mg} / \mathrm{kg} /$ day). A few days later, his pain was decreased and one week after the treatment started, a significant resolution of swelling was observed. For two weeks, he had taken full dose of oral prednisolone treatment and the dose was tapered gradually. He took total four weeks of corticosteroid treatment.

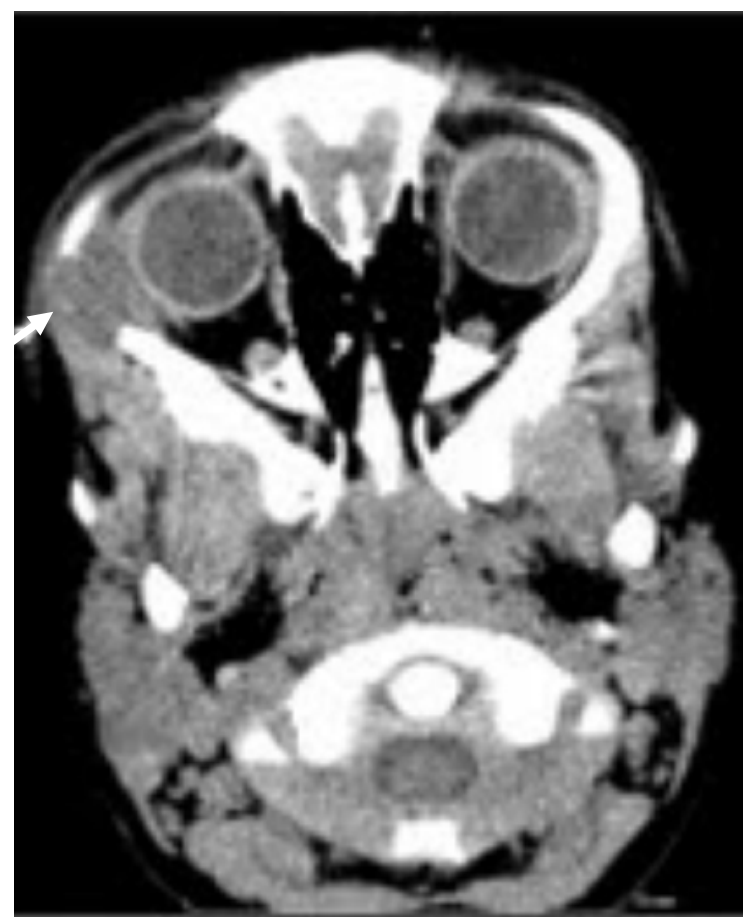

Figure 2. Axial computed tomography image demonstrates a hypodens rounded shaped soft tissue lesion at the lateral wall of the right orbit with bone destruction (arrow)

After six months his control CT scan indicated the resolution of mass and bone destruction when compared to the first imagining before the treatment (Figure 3). Together with the corticosteroid treatment, excellent response was observed. The problems like the orbital swelling; ptosis, pain or hypersensitivity was completely solved. During a 9 months follow up, there was not relapse. 


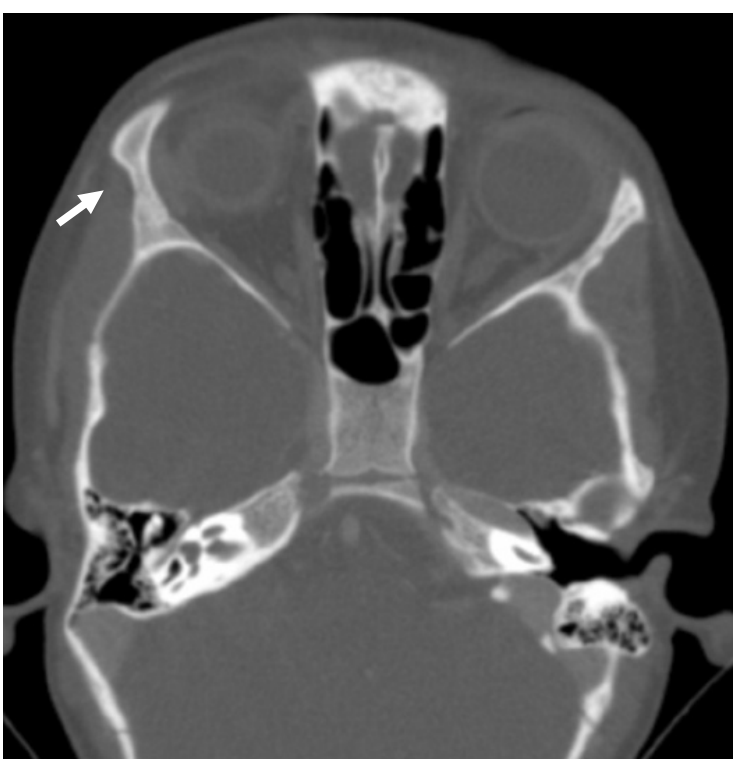

Figure 3. Control CT image shows the intact lateral orbital wall and sclerosis of the healed bone (arrow).

\section{Discussion}

Orbits and lungs are the most common places that pseudotumors can be observed. There is no specific laboratory or imaging findings for the existence of orbital pseudotumor. Especially for children, the elevation of erythrocyte sedimentation rate, white blood count and peripheral eosinophilia can be seen [5]. For our patient; although erythrocyte sedimentation rate was in normal range, peripheral and histologically eosinophilia was observed. Pathologic examination shows nonspecific inflammation with eosinophil dominance, as in our case [2, 6-8]. For children, the differential diagnosis includes orbital cellulites, thyroid ophtalmopathy, langerhans cell histiocytosis, malignancies (eg. neuroblastoma, rabdomysarkoma, optic nerve glioma, leukemic infiltrate) [9]. For exclusion of malignancy histopathologic examination was done for our patient, which shows nonspecific chronic inflammation but immunohistochemically it was negative for CD1 and S100, so we could eliminate also the diagnosis of histiocytosis. His thyroid function tests were normal and he did not have any symptom for thyroid disorders. Imaging studies are generally needed in order to make differential diagnosis of orbital cellulites and malignancy. CT and MRI of orbital pseudotumor include fibrous nature of orbital mass, optic nerve and extra ocular muscle together with soft tissue enlargement; rarely bone destruction and intracranial extension [110]. Only four adult orbital pseudotumor cases were reported in relation with bone destruction.
In our case, MRI and CT scan demonstrated mass lesion that caused the bone destruction. As our search in literature, there is not any pediatric orbital pseudotumor case, causing bone destruction.

The most important treatment modality for orbital pseudotumor is corticosteroids. For steroid resistant cases radiation therapy or immunosuppressants are another choice, especially for adult patients [9]. Three of adult orbital pseudotumor cases with bone destruction need radiation therapy for resolution, however in our case there were no needs for any further therapy $[3,4]$. For our case after corticosteroid treatment control MRI findings confirmed the resolution of mass and bone destruction. The patient has also shown clinical improvement after treatment.

In our case, the orbital pseudotumor caused bone destruction and corticosteroid treatment was enough for both disappearance of main symptoms and resolution of bone destruction. As we know, there is no orbital pseudotumor case for children, which causes bone destruction and therefore it is usually unlikely to observe the recovery of this destruction.

Conflict of interest: The authors declared no conflict of interest.

For publication of case verbal permission was taken from patients' parents.

\section{References}

1. Weber AL, Romo LV, Sabates NR. Pseudotumor of the orbit: Clinical, pathologic, and radiologic evaluation. RadiolClin North Am 1999;37:151-168.

2. Yan J, Qui H, Wu Z, Li Y, Idiopathic orbital inflammatory pseudotumors in Chinese children. Orbit 2006; 25:1-4.

3. Frohman LP, Kupersmith MJ, Lang J, et al. Intracranial extension and bone destruction in orbital pseudotumor. Arch Ophthalmol 1986;1043:380-384.

4. Whyte IF, Young JD, Guthrie W, Kemp EG. Orbital inflammatory disease and bone destruction. Eye (Lond) 1992;6:662-666.

5. Mottow-Lippa L, Jakobiec FA, Smith M. Idiopathic inflammatory orbital pseudotumor in childhood. II. Results of diagnostic tests and biopsies. Ophthalmology 1981;88:565-574.

6. Stevens JL, Rychwalski PJ, Baker RS, Kielar RS. Pseudotumor of the orbit in early childhood. J AAPOS. 1998;2.120-123.

7. Mulvihill A, Smith C, Buncic J. Pediatric orbital pseudotumor presenting as a painless orbital and periocular mass. Can J Ophthalmol. 2004;39.77-79.

8. Brannan PA, Kersten RC, Kulwin DR. Sclerosing idiopathic orbital inflammation. J Pediatr Ophthalmol Strabismus 2006;43.183-184. 
9. Guerriero S, Di Leo E, Piscitelli D, et. al. Orbital pseudotumor in a child: diagnostic implications and treatment strategies. Clin Exp Med 2011;11:61-63.

10. Char DH, Miller T. Orbital pseudotumor: fineneedle aspiration biopsy and response to therapy. Ophthalmology 1993;100:1702-10. 